\title{
Effect of antenatal retroviral therapy on feto-maternal outcome in human immunodeficiency virus seropositive patients
}

\author{
Swati Trivedi $^{1 *}$, Oby Nagar ${ }^{1}$, Shashank Trivedi², Prasoon Rastogi ${ }^{3}$
}

\author{
${ }^{1}$ Department of Obstetrics and Gynecology, S. M. S. Medical College, Jaipur, Rajasthan, India \\ ${ }^{2}$ Department of Pediatrics, K. E. M., Pune, Maharashtra, India \\ ${ }^{3}$ Department of Medicine, K. G. M. U., Lucknow, Uttar Pradesh, India
}

Received: 08 April 2020

Accepted: 30 May 2020

\section{*Correspondence:}

Dr. Swati Trivedi,

E-mail: krishnaagnihotri.kgmc@gmail.com

Copyright: () the author(s), publisher and licensee Medip Academy. This is an open-access article distributed under the terms of the Creative Commons Attribution Non-Commercial License, which permits unrestricted non-commercial use, distribution, and reproduction in any medium, provided the original work is properly cited.

\section{ABSTRACT}

Background: To study the effect of HIV and duration of ART on term of delivery, newborn birth weight and adverse fetal outcomes.

Methods: Prospective comparative study of $40 \mathrm{HIV}$ seropositive pregnant females with varying duration of ART (tenofovir $300 \mathrm{mg}+$ lamivudine $300 \mathrm{mg}$ + efavirenz $600 \mathrm{mg}$ ) and HIV seronegative pregnant females attending ANC and delivering in department of obstetrics and gynecology at S. M. S. Medical College, Jaipur, Rajasthan, India.

Results: Most HIV seropositive patients were in age group 25 to 30 years and more number were booked in comparison to unbooked. Adverse fetal outcomes were seen more in HIV seropositive patients and they were found to be statistically significant $(\mathrm{p}=0.029)$. No relationship could be derived of duration of ART on either the birth weight or term of delivery or adverse fetal outcomes.

Conclusions: Maternal HIV infection was significantly found associated with adverse fetal outcome and this was not affected by the use of ART.

Keywords: Adverse fetal outcomes, ART, Human immunodeficiency virus, Term of delivery

\section{INTRODUCTION}

AIDS (acquired immune deficiency syndrome), sometimes called wasting disease or slim disease is a fatal illness caused by a retrovirus known as the "human immunodeficiency virus" (HIV) which breaks down the body's immune system, leaving the victim vulnerable to be a host of life threatening opportunistic infections, neurological disorders and unusual malignancies. AIDS being the end stage of HIV infection. ${ }^{1}$

The causative virus is transmitted from person to person most frequently through sexual activity. HIV can also be transmitted by contaminated blood, injection drug abusers and from an infected mother to her baby (through the placenta or during delivery or by breast feeding). HIV infected people are more prone to infect others in early stages before antibody production i.e. during the "window period" and when the infection is well advanced, because level of virus is highest in blood at these times. ${ }^{1}$

HIV infection/AIDS is a pandemic with cases reported from virtually every country. Recognised as an emerging disease in early 1980's, AIDS has rapidly established itself throughout the world. India has the $3^{\text {rd }}$ largest HIV epidemic in the world. As per the recently released, India HIV Estimation 2017 report, National adult (15-49 years) HIV prevalence in India is estimated at $0.22 \%(0.16 \%$ $0.30 \%$ ) in 2017. Estimated number of people living with HIV/AIDS in India is 2.11 million with $0.29 \%$ being antenatal clinic attendees. ${ }^{2-5}$ 


\section{METHODS}

This is prospective-comparative study 40 HIV seropositive and 40 seronegative pregnant women attending ANC and delivering in the department of obstetrics and gynecology at S. M. S. Medical College and attached hospitals, Jaipur, Rajasthan, from May 2018 to November 2019.

\section{Inclusion criteria}

- Women delivering in study hospital with regular ANC visits (Both HIV seropositive and negative)

- Patients giving consent for study and willing for follow up of mother and child

- $\quad$ HIV positive females (both on ART/ not on ART)

- $\quad$ Patients with period of gestation $(\mathrm{POG})>28$ weeks.

\section{Exclusion criteria}

- Individuals refusing for HIV testing

- Other immunodeficiency disorder

- IUGR for other causes

- Severe anaemia, HDP, thyroid disorders.

Pregnant females attending ANC for regular check-up were evaluated after written informed consent. HIV testing done and the patients were divided into two groups after application of inclusion and exclusion criteria:
- Group A - seronegative pregnant females

- Group B - seropositive pregnant females.

Detailed history was taken and physical examination done. Baby parameters (weight, Apgar, etc) were obtained. Biochemical investigations were done for both mother and baby.

\section{Statistical analysis}

A pre structured proforma was used to collect patient data. Analysis was done using unpaired t test, chi square test and fisher exact test. MEDCALC software was used for all statistical analysis.

\section{RESULTS}

In Table 1, most of the subjects in sero-positive (case) group were in age group 25 to 30 years $(42.5 \%)$ while most of the subjects in sero-negative (control) group were in the age group $<25$ years $(55 \%)$. The differences in age distribution were not found to be statistically significant $(\mathrm{p}=0.153)$.

As shown in Table 2, among the seropositive group i.e. cases, $65 \%$ patients were booked and $35 \%$ were unbooked. While in the control group i.e. seronegative, $70 \%$ patients were booked and $30 \%$ unbooked. The difference was not found to be statistically significant $(\mathrm{p}=0.811)$.

Table 1: Age distribution of study groups.

\begin{tabular}{|c|c|c|c|c|c|c|}
\hline \multirow{2}{*}{$\begin{array}{l}\text { Age group } \\
\text { (years) }\end{array}$} & \multicolumn{2}{|c|}{ Case } & \multicolumn{2}{|c|}{ Control } & \multicolumn{2}{|c|}{ Total } \\
\hline & $\mathbf{N}$ & $\%$ & $\mathbf{N}$ & $\%$ & $\mathbf{N}$ & $\%$ \\
\hline$<25$ & 16 & $40 \%$ & 22 & $55 \%$ & 38 & $47.5 \%$ \\
\hline $25-30$ & 17 & $42.5 \%$ & 16 & $40 \%$ & 33 & $41.25 \%$ \\
\hline$>30$ & 7 & $17.5 \%$ & 2 & $5 \%$ & 9 & $11.25 \%$ \\
\hline Total & 40 & $100 \%$ & 40 & $100 \%$ & 80 & $100 \%$ \\
\hline
\end{tabular}

Chi-square $=3.755$ with 2 degrees of freedom; $p=0.153$ (NS).

Table 2: Distribution of study groups according to booking status.

\begin{tabular}{|c|c|c|c|c|c|c|}
\hline \multirow{2}{*}{ Booking status } & \multicolumn{2}{|c|}{ Case } & \multicolumn{2}{|c|}{ Control } & \multicolumn{2}{|c|}{ Total } \\
\hline & $\mathbf{N}$ & $\%$ & $\mathbf{N}$ & $\%$ & $\mathbf{N}$ & $\%$ \\
\hline Booked & 26 & $65 \%$ & 28 & $70 \%$ & 54 & $67.5 \%$ \\
\hline Un-booked & 14 & $35 \%$ & 12 & $30 \%$ & 26 & $32.5 \%$ \\
\hline Total & 40 & $100 \%$ & 40 & $100 \%$ & 80 & $100 \%$ \\
\hline
\end{tabular}

Chi-square $=0.057$ with 1 degree of freedom; $p=0.811(\mathrm{NS})$.

Table 3: Term of delivery among study groups.

\begin{tabular}{|c|c|c|c|c|c|c|}
\hline \multirow{2}{*}{ Term of delivery } & \multicolumn{2}{|c|}{ Case } & \multicolumn{2}{|c|}{ Control } & \multicolumn{2}{|c|}{ Total } \\
\hline & $\mathbf{N}$ & $\%$ & $\mathbf{N}$ & $\%$ & $\mathbf{N}$ & $\%$ \\
\hline Term & 36 & $90 \%$ & 39 & $97.5 \%$ & 75 & $93.75 \%$ \\
\hline Preterm & 4 & $10 \%$ & 1 & $2.5 \%$ & 5 & $6.25 \%$ \\
\hline Total & 40 & $100 \%$ & 40 & $100 \%$ & 80 & $100 \%$ \\
\hline
\end{tabular}

Fisher exact test $-\mathrm{p}=0.359$ (NS). 
In Table 3, among the seropositive group, 4 patients $(10 \%)$ had preterm delivery i.e. $<37$ weeks while in the control group, 1 patient $(2.5 \%)$ had preterm delivery. Though the difference in the two group are evident but the results are not statistically significant $(\mathrm{p}=0.359)$.

The given Table 4 depicts the term of delivery in relation to duration of ART. Of 29 seropositive patients on ART for $<9$ months, $3(10.3 \%)$ had preterm delivery and 26 $(89.7 \%)$ were delivered at term. While the other group with 11 patients on ART for $>9$ months, $1(9.1 \%)$ patient had preterm delivery. The differences in the results were not found to be statistically significant $(\mathrm{p}=1.000)$.

As per Table 5, in the seropositive mother group/cases, 8 babies born of 40 had weight $<2.5 \mathrm{~kg}$ i.e. LBW (low birth weight) while in the seronegative mother group/control, 9 babies born of 40 were LBW. The differences were not found to be statistically significant $(\mathrm{p}=0.486)$.

Table 4: Term of delivery in relation to duration of ART.

\begin{tabular}{|lllllll|}
\multirow{2}{*}{ Term of delivery } & \multicolumn{2}{l}{ ART $<\mathbf{9}$ months } & ART $>\mathbf{9}$ months & Total & \\
\cline { 2 - 7 } & $\mathbf{N}$ & $\mathbf{\%}$ & $\mathbf{N}$ & $\mathbf{\%}$ & $\mathbf{N}$ & $\mathbf{4}$ \\
\hline Preterm & 3 & $10.3 \%$ & 1 & $9.1 \%$ & 4 & $10 \%$ \\
\hline Term & 26 & $89.7 \%$ & 10 & $90.9 \%$ & 36 & $90 \%$ \\
\hline Total & 29 & $100 \%$ & 11 & $100 \%$ & 40 & $100 \%$ \\
\hline
\end{tabular}

Fisher exact test $-\mathrm{p}=1.000(\mathrm{NS})$.

Table 5: New born birth weight among study groups.

\begin{tabular}{|c|c|c|c|c|c|c|}
\hline \multirow{2}{*}{$\begin{array}{l}\text { Birth weight } \\
\text { (kg) }\end{array}$} & \multicolumn{2}{|c|}{ Case } & \multicolumn{2}{|c|}{ Control } & \multicolumn{2}{|c|}{ Total } \\
\hline & $\mathbf{N}$ & $\%$ & $\mathbf{N}$ & $\%$ & $\mathbf{N}$ & $\%$ \\
\hline$<2.5 \mathrm{~kg}$ & 8 & $20 \%$ & 9 & $22.5 \%$ & 17 & $21.25 \%$ \\
\hline$\geq 2.5 \mathrm{~kg}$ & 32 & $80 \%$ & 31 & $77.5 \%$ & 63 & $78.75 \%$ \\
\hline Total & 40 & $100 \%$ & 40 & $100 \%$ & 80 & $100 \%$ \\
\hline Mean \pm SD & \multicolumn{2}{|c|}{$2.73 \pm 0.09 \mathrm{~kg}$} & \multicolumn{4}{|c|}{$2.81 \pm 0.47 \mathrm{~kg}$} \\
\hline
\end{tabular}

Chi-square $=0.000$ with 1 degree of freedom, $\mathrm{p}=1.000(\mathrm{NS}), \mathrm{t}=-0.699$ with 78 degrees of freedom; $\mathrm{p}=0.486$ (NS).

Table 6: New born birth weight in relation to duration of ART.

\begin{tabular}{|c|c|c|c|c|c|c|}
\hline \multirow{2}{*}{ Birth weight (kg) } & \multicolumn{2}{|c|}{ ART $<9$ months } & \multicolumn{2}{|c|}{ ART $>9$ months } & \multicolumn{2}{|c|}{ Total } \\
\hline & $\mathbf{N}$ & $\%$ & $\mathbf{N}$ & $\%$ & $\mathbf{N}$ & $\%$ \\
\hline$<2.5 \mathrm{~kg}$ & 6 & $20.7 \%$ & 2 & $18.2 \%$ & 8 & $20 \%$ \\
\hline$\geq 2.5 \mathrm{~kg}$ & 23 & $79.3 \%$ & 9 & $81.8 \%$ & 32 & $80 \%$ \\
\hline Total & 29 & $100 \%$ & 11 & $100 \%$ & 40 & $100 \%$ \\
\hline
\end{tabular}

Fisher exact test $-\mathrm{p}=1.000$ (NS).

Table 7: Adverse fetal outcome among study groups.

\begin{tabular}{|lllllll|}
\hline Fetal outcome & Case & \multicolumn{3}{c}{ Control } & \multicolumn{2}{c|}{ Total } \\
\cline { 2 - 6 } & $\mathbf{N}$ & $\mathbf{\%}$ & $\mathbf{N}$ & $\mathbf{\%}$ & $\mathbf{N}$ & $\mathbf{\%}$ \\
\hline Favourable & 32 & $80 \%$ & 39 & $97.5 \%$ & 71 & $88.75 \%$ \\
\hline Adverse & 8 & $20 \%$ & 1 & $2.5 \%$ & 9 & $11.25 \%$ \\
\hline Total & 40 & $100 \%$ & 40 & $100 \%$ & 80 & $100 \%$ \\
\hline
\end{tabular}

Fisher exact test $-\mathrm{p}=0.029$ (NS).

Table 8: Adverse fetal outcome in relation to duration of ART.

\begin{tabular}{|lllllll|}
\hline \multirow{2}{*}{ Fetal outcome } & ART $<9$ months & ART $>$ months & \multicolumn{2}{c|}{ Total } \\
& $\mathbf{N}$ & $\mathbf{\%}$ & $\mathbf{N}$ & $\mathbf{\%}$ & $\mathbf{N}$ & $\mathbf{\%}$ \\
\hline Favourable & 23 & $79.3 \%$ & 9 & $81.8 \%$ & 32 & $80 \%$ \\
\hline Adverse & 6 & $20.7 \%$ & 2 & $18.2 \%$ & 8 & $20 \%$ \\
\hline Total & 29 & $100 \%$ & 11 & $100 \%$ & 40 & $100 \%$ \\
\hline
\end{tabular}

Fisher exact test $-\mathrm{p}=1.000$ (NS). 
Table 6 predicts the relationship of new-born birth weight with respect to duration of ART. In this study, 29 seropositive patients (mothers) were on ART for $<9$ months, of which $20.7 \%$ gave birth to babies $<2.5 \mathrm{~kg}$ i.e. LBW and $79.3 \%$ had babies $\geq 2.5 \mathrm{~kg}$. Of the remaining 11 patients on ART for $>9$ months, $18.2 \%$ had LBW babies and $81.8 \%$ had babies $\geq 2.5 \mathrm{~kg}$. The differences in birth weight in the two groups were not found to be statistically significant $(\mathrm{p}=1.000)$.

Table 7 compares adverse fetal outcomes in terms of IUD, still birth and preterm birth in the two study groups. Of the 40 seropositive cases, 8 (20\%) fetal outcomes were adverse while in the seronegative control group, 1 $(2.5 \%)$ of 40 fetal outcome was adverse. The result was found to be statistically significant with $\mathrm{p}$-value $<0.05$. $(\mathrm{p}=0.029)$.

Table 8 illustrates the adverse fetal outcome in relation to the duration of ART. Among 29 patients with duration of ART $<9$ months, 6 babies $(20.7 \%)$ had adverse outcomes in terms of IUD, still birth and Preterm birth; while in the other group where patients were on ART $>9$ month, out of total 11 babies born, $2(18.2 \%)$ had adverse outcome with 9 being favourable/uneventful. The difference in results of adverse outcome with duration of ART were not found to be statistically significant $(\mathrm{p}=1.000)$.

\section{DISCUSSION}

The mean age of HIV seropositive patients was 26.16 years with maximum number of patients lying in the age group 25 to 30 years $(42.5 \%)$. Mean age in study done by Dwivedi et al was found to be 25.2 years which is comparable; while in study done by Prameela et al and Ezechi et al, the mean age were 23 years and 30 years respectively. ${ }^{6-8}$ The mean age of HIV seronegative patients in this study was 24.5 years with more number of patients in age $<25$ years $(55 \%)$.

More number of patients in both HIV seropositive and HIV seronegative group were booked $65 \%$ and $70 \%$ respectively. The difference is not significant. This could be attributed to easy accessibility of health services and ART centres at various places for HIV seropositive patients under NACO's initiative.

The mean birth weight in HIV seropositive group was $2.73 \pm 0.09 \mathrm{~kg}$ and that in HIV seronegative was $2.81 \pm 0.47$ $\mathrm{kg}$. $20 \%$ babies born in HIV seropositive group were LBW (birth weight $<2.5 \mathrm{~kg}$ ) while in HIV seronegative group $22.7 \%$ were LBW. The differences were not statistically significant. Also, there was no significant relationship of duration of ART with birth weight of the baby/ LBW. Among seropositive group, $10 \%$ patients delivered preterm while in seronegative group preterm deliveries were only $2.5 \%$. The differences were not statistically significant. Also, there was no relationship of preterm delivery with maternal duration of ART. The inference of the above observations may be due to improved infrastructure of health care bringing about earlier detection of HIV disease, awareness among the 'at risk' population, availability of HAART and active government policies to cater the diseased effectively. Similar results were found in study done by Schulte et al, who reported a decline in the rates of low-birth-weight infants and preterm infants. ${ }^{9}$ Also all women in this study were asymptomatic and diagnosed in early stages which decreased the incidence of preterm labour and low birth weight as was found in study done by Coley et al, in Tanzania which suggested that although HIV infected asymptomatic women did not have a higher risk of having LBW infants compared with uninfected women, symptomatic HIV-infected women (who were in stage 2 or higher according to the WHO staging system) had about 2-times higher risks for low birth weight and prematurity compared with HIV-uninfected ones. ${ }^{10}$ This is consistent with the finding of Bucceri et al, and Muhangi et al. ${ }^{11,12}$ Brocklehurst et al, reported that the increasing risks of LBW and PTD were associated with maternal HIV infection. ${ }^{13}$ Xiao PL et al, concluded that maternal HIV infection increased the risks of both LBW and PTD. ${ }^{14}$ Townsend et al also concluded that HAART was associated with PTD. ${ }^{15}$ ARVs might be responsible for adverse pregnancy outcomes such as LBW and PTD, but its high effectiveness in the prevention for mother to child transmission outweighed its risk of LBW/PTD suggested by Santini et al. ${ }^{16}$ This could be explained by the fact that protease inhibitor based ART when used, it lowered the level of progesterone resulting in preterm labour and low birth weight. Papp et al, suggested that protease inhibitor (PI)-based ART could increase the risk of adverse pregnancy outcomes mainly due to lower level of progesterone, which was significantly associated with fetal weight. ${ }^{17}$ Sibude et al also found that ARVs and, particularly, with the initiation of ritonavir-boosted PI therapy during pregnancy were correlated with PTD in HIV infected women. ${ }^{18}$ Xiao PL et al, in their study found that HAART or other regimens of antiretroviral therapy (ART) had no obvious effect on the associations between maternal HIV infection and LBW/PTD; intrauterine $A R V s$ exposure did not decrease or increase the risk of LBW or PTD in HIV infected women. ${ }^{14}$ And this is consistent with the findings reported by Van der Merwe et al and Townsend et al. ${ }^{19,20}$

There was an increased incidence of adverse fetal outcomes in terms of IUD, still birth and preterm birth $20 \%$ in HIV seropositive patients in contrast to $2.5 \%$ in HIV seronegative pregnancies. The differences were found to be statistically significant $(\mathrm{p}=0.029)$. Kennedy D et al, found a still birth rate of $1.7 / 1000$ births in HIV seropositive population compared to $8.3 / 1000$ in HIV seronegative population. ${ }^{21}$ Kumar et al from India, matched 160 HIV infected pregnant women with uninfected control and found that HIV infection had a detrimental effect on pregnancy in terms of abortion, prematurity, intrauterine fetal death and maternal and neonatal mortality. ${ }^{22}$ Similar results were found in various studies done by Ezechi et al, Ellis et al, 
Brocklehurst et al and Dwivedi et al. ${ }^{6,8,13,23}$ In India, studies done by Gautam $\mathrm{S}$ et al and Prameela et al found still birth rate to be comparatively less $3.1 \%$ and $3.9 \%$ respectively. ${ }^{7,24}$

In this study authors found no relationship of duration of ART on adverse fetal outcomes. Similar results were found in study by Haeri et al, which compared $151 \mathrm{HIV}$ infected women on HAART and 302 HIV uninfected women. Neonatal outcomes were similar, HAART did not increase maternal complications. On the contrary studies by Parisaei et al, Patil S et al and Fekadu M et al reported adverse perinatal complications in women who received ART. ${ }^{26-28}$

\section{CONCLUSION}

Despite the social stigma regarding HIV, a greater number of HIV seropositive patients are getting themselves booked due to better availability of health services and easy accessibility to ART centres. In this study authors found that neither HIV infection nor ART (irrespective of duration) had any detrimental effect on term of delivery or birth weight of baby. HIV infected women have been found to have more adverse fetal outcomes in comparison to HIV uninfected women. Since all patients in this study were on ART, it becomes difficult to analyse whether the adverse outcomes were due to ART or due to HIV infection.

Funding: No funding sources Conflict of interest: None declared

Ethical approval: The study was approved by the Institutional Ethics Committee

\section{REFERENCES}

1. Park K. Epidemiology of communicable diseases, Park's textbook of preventive and social medicine. Bhanot Publishers;2015;5:343-347.

2. Larry J. Harrison's Principles of Internal Medicine Chapter 197: Human Immunodeficiency Virus Disease: AIDS and related disorders, 20th edition; 2018;1393-1402.

3. NACO (National AIDS Control Organization) Annual Report NACO 2016-17 English. Available at: http://naco.gov.in/documents/annual-reports. Accessed on $4^{\text {th }}$ January 2020.

4. HIV Facts and figures: NACO, Available at http://naco.gov.in/hiv-facts-figures Accessed on 4th January 2020.

5. National AIDS Control Organization Ministry of Health and Family Welfare Government of India: National technical guidelines on anti-retroviral treatment. NACO: 2018:7:50-9.

6. Dwivedi S, Jahan U, Dwivedi GN, Gupta N, Verma $\mathrm{K}$, Sharma B, et al. Perinatal outcome in HIV infected pregnant women at tertiary care Hospital in north India: eleven years retrospective study. Int J Recent Sci Res.2017;8(5):16801-05.
7. Prameela RC, Asha MB, Bhanumathi, Geetha T, Vasumathy S, Shankar R. Maternal and Fetal Outcome in HIV pregnant women, 5 years study at tertiary hospital. J Dent Med Sci. 2015;14(3):53-6.

8. Ezechi OC, Gab Okafor CV, Oladele DA, Kalejaiye OO, Oke BO, Ohowodo HO, et al. Pregnancy, obstetrics and neonatal outcomes in HIV positive Nigerian women. Afr J Reprod Health. 2013;17(3): 160-8.

9. Schulte J, Dominguez K, Sukalac T, Bohannon B, Fowler MG. Declines in low birth weight and preterm birth among infants who were born to HIVinfected women during an era of increased use of maternal antiretroviral drugs: Pediatric Spectrum of HIV Disease, 1989-2004. Pediatr. 2007;119:e900e906.

10. Coley JL, Msamanga GI, Fawzi M. The association between maternal HIV-1 infection and pregnancy outcomes in Dar es Salaam Tanzania. BJOG. 2001;108(11):1125-33.

11. Bucceri A, Luchini L, Rancilio L. Pregnancy outcome among HIV positive and negative intravenous drug users. Eur J Obstet Gynecol Reprod Biol. 1997;72(2):169-74.

12. Muhangi L, Lule SA, Mpairwe H. Maternal HIV infection and other factors associated with growth outcomes of HIV-uninfected infants in Entebbe Uganda. Public Health Nutr. 2013;16(9):1548-57.

13. Brocklehurst P, French R. The association between maternal HIV infection and perinatal outcome: a systemic review of the literature and meta-analysis. Br J Obstet Gynecol. 1998;105:839-48.

14. Xiao PL, Zhou YB, Chen Y, Yang MX, Song XX, Shi $Y$, et al. Association between maternal HIV infection and low birth weight and prematurity: a meta-analysis of cohort studies. BMC Preg Childbirth. 2015;15:246.

15. Townsend C, Schulte J, Thorne C. Antiretroviral therapy and preterm delivery-a pooled analysis of data from the United States and Europe. BJOG. 2010;117(11):1399-410.

16. Santini-Oliveira M, Friedman RK, Veloso VG. Incidence of antiretroviral adverse drug reactions in pregnant women in two referral centers for HIV prevention of mother-to-child-transmission care and research in Rio de Janeiro Brazil. Braz J Infect Dis. 2014;18(4):372-8.

17. Papp E, Mohammadi H, Loutfy MR. HIV protease inhibitor use during pregnancy is associated with decreased progesterone levels, suggesting a potential mechanism contributing to fetal growth restriction. J Infect Dis. 2015;211(1):10-8.

18. Sibiude J, Warszawski J, Tubiana R. Premature delivery in HIV-infected women starting protease inhibitor therapy during pregnancy: role of the ritonavir boost? Clin Infect Dis. 2012;54(9):1348-60.

19. Van der Merwe K, Hoffman R, Black V. Birth outcomes in South African women receiving highly active antiretroviral therapy: a retrospective observational study. J Int AIDS Soc. 2011;14(1):42. 
20. Townsend CL, Cortina-Borja M, Peckham CS, Tookey PA. Antiretroviral therapy and premature delivery in diagnosed HIV-infected women in the United Kingdom and Ireland. AIDS. 2007;1019-26.

21. Kennedy D. The effect of maternal HIV status on perinatal outcome at Mowbray Maternity Hospital and referring midwife obstetric units, Cape Town. SAJOG. 2012;18:1.

22. Kumar RM, Uduman SA, Khurrana AK. Impact of maternal HIV-1 infection on perinatal outcome. Int J Gynaecol Obstet. 1995; 49:137-43.

23. Ellis J, Williams H, Graves W. Human immunodeficiency virus infection is a risk factor for adverse perinatal outcome. Am J Obstet Gynecol. 2002;186:903-6.

24. Gautam S, Shah T. Study of perinatal outcome in human immunodeficiency virus positive women. Int J Reprod Contracept Obstet Gynecol. 2016;5(8):2587-90.

25. Haeri S, Shauer M, Dale M, Leslie J, Baker AM, Saddlemire S, Boggess K. Obstetric and newborn infant outcomes in human immunodeficiency virusinfected women who receive highly active antiretroviral therapy. Am J Obstet Gynecol. 2009;201:315.e1-5.

26. Parisaei M, Anderson J, Erskine KJ, Gann S. Experience of delivering women with HIV in an inner-city London hospital. Int J STD AIDS. 2007;18(8):227-30.

27. Patil S, Bhosale R, Sambarey P, Gupte N, Suryavanshi N, Sastry J, et al. Impact of maternal human immunodeficiency virus infection on pregnancy and birth outcomes in Pune, India. AIDS Care. 2011;23(12):1562-69.

28. Fekadu M, Alemayehu W, Mesganaw F, Eta E. Antiretroviral therapy and pregnancy outcomes in developing countries: a systematic review. Int $\mathrm{J}$ MCH AIDS. 2015;3(1):31-43.

Cite this article as: Trivedi S, Nagar O, Trivedi S, Rastogi P. Effect of antenatal retroviral therapy on feto-maternal outcome in human immunodeficiency virus seropositive patients. Int J Reprod Contracept Obstet Gynecol 2020;9:2364-9. 